\title{
The Use of Biosensor as a New Trend in Cancer: Bibliometric Analysis from 2007 to 2017
}

\author{
Delfino $\mathrm{CSC}^{1,2}$, Perez Cordovés $\mathrm{AI}^{1}$ and Souza Jr FG ${ }^{1,3 *}$ \\ ${ }^{1}$ Instituto de Macromoléculas, Brasil \\ ${ }^{2}$ Faculdade de Farmácia, Brasil \\ ${ }^{3}$ Programa de Engenharia Civil, Brasil \\ *Corresponding author: Souza Jr FG, Instituto de Macromoléculas, Programa de Engenharia Civil, Brasil
}

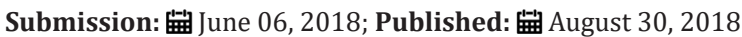

\begin{abstract}
Nanotechnology is a multidisciplinary field that covers large areas of chemistry, physics, and biology as well as engineering. The application in medicine for diagnosis, prevention, and treatment of diseases, has become known as nanomedicine and is now an excellent tool for new nanotechnological applications, such as the use of biosensors. This study aimed to analyze bibliometrics related to applications in biosensors and the relative importance of these publications in cancer. The search base for articles was Google Scholar, due to the higher coverage of articles published in comparison to other databases of scientific publications, such as Pubmed and Science Direct. The obtained results showed that there was a decrease in the number of publications referring to cancer at the last decade (2007-2017), but there was an increase in the number of publications regarding the use of biosensors, showing an interest and tendency using new technologies for clinical diagnosis. Nanotechnology is a promising tool for the development of new diagnostic methods and its growth for the next decades is undeniable, including biosensors.
\end{abstract}

Keywords: Biosensor; Cancer; Nanotechnology

\section{Introduction}

Nanotechnology is a multidisciplinary science, encompassing the areas of engineering, biology, chemistry and physics, being more and more applied in medicine and pharmacy [1-6]. Nanotechnology's applications range from drug release studies to the use of biosensors as a tool for the early diagnosis in several diseases, as well as the treatment of drugs and antibodies in target systems in diseases such as cancer [7-10].

Biosensors are small devices that combine a biological component with a target substrate, which allows for the formation of the electrochemical signal through a bio-reacquisition reaction, allowing this signal to be measured through a physical transducer [7,11-18]. This biomolecular recognition is essential for a biosensor and, initially, the recognition elements of a biosensor were isolated from living systems. However, it is now possible to synthesize these elements in laboratories [19]. Their applications may include detection of proteins [20-37], viruses [38-56], antibodies [57-74], DNA [75-89], drugs [90-100], pesticides [101-119] and other low molecular weight compounds [120-123].

The interest of the use of biosensors for early detection in cancer using nanotechnology is of great importance for early clinical diagnosis and consequently to contribute to the reduction of mortality as well as to the improvement of the quality of life of the population [124-133].

Cancer is the second leading cause of death worldwide [134144]. Thus, the use of biosensors has become a promising tool for early diagnosis, since the risk of metastasis is a critical point in the development of the disease, rapidly causing the death of the individual. Because tumor cells are present at shallow levels in peripheral blood, they can be detected in patients with advanced tumors with or without metastasis. Thus, the present study analyzed bibliometrics related to applications in biosensors and the relative importance of these publications in cancer. The obtained results showed that there was a decrease in the number of publications referring to cancer at the last decade (2007-2017), but there was an increase in the number of publications regarding the use of biosensors, showing an interest and tendency using new technologies for clinical diagnosis

\section{Experimental}

The methodology used in this study was based on the use of the Google Scholar database for the bibliometrics of scientific productions. In this database it is possible to have a broader search of publications, due to the more excellent coverage of journals. 
Search bases such as Scopus $₫$, Web of Science $₫$, and Compendex $₫$ have their metrics, and when we join these three databases in a single search, there may be discrepancies in citation numbers, as well as articles contained in all of them [145]. Google Scholar ${ }^{\circledR}$ will fetch all articles using the same metric. For the bibliometrics of scientific productions in the last decade, keywords were used for the use of biosensors and their applications in cancer in specific periods from 2007 to 2017. The applications in biosensors used were diagnostic, bio-detection, biomarker, prevention, biomaterial, nanoparticles, graphene, tattoos and Point-of-care (POC).

To analyze the impact of nanotechnology with biosensors on the scientific production of cancer in the last decade, a calculation was performed aiming to obtain the relative importance based on the publications of biosensors and their applications in cancer and the total number of scientific productions in cancer (Table 1).

Table 1: Relative Importance and Tendency in cancer and biosensors applications.

\begin{tabular}{|c|c|c|c|}
\hline Year & Biosensor+Cancer+Diagnosis & Cancer & RI (\%) \\
\hline 2007 & 2.78 & 1.240 .000 & 0.181 \\
\hline
\end{tabular}

From the relative importance of publications in biosensors for each application in cancer followed year by year, a tendency curve was prepared using an exponential model for a higher sensitivity of the obtained data, as well as the equation and value of $R^{2}$ (coefficient of determination) for a better fit of the statistical model. The value of $R^{2} \geq 0.9(90 \%)$ was used as the reliability criterion of the results obtained through bibliometrics analysis.

\section{Results and Discussion}

In the last decade, the publications about cancer suffered a decrease. For instance, 2017 produced around $144 \mathrm{~K}$ scientific publications, whereas in 2007 more than 1.1 million publications were produced. This observed decrease in bibliometrics during the last decade is shown in Table 2 and Figure 1. Regarding cancer, in 2007 , around $0.18 \%$ of cancer publications were associated with the use of biosensors for diagnosis and in 2017, this number increased to $6.62 \%$ of total cancer publications, as shown in Table 3. Figure
2 shows the Tendency Curve for cancer diagnosis, allowing for inferring an exponential increase with $\mathrm{R}^{2}$ equals to 0.9301 (93\%).

Table 2: The bibliometrics in cancer (2007-2017).

\begin{tabular}{|c|c|}
\hline Year & Cancer \\
\hline 2007 & 1.240 .000 \\
\hline 2008 & 1.180 .000 \\
\hline 2009 & 1.090 .000 \\
\hline 2010 & 1.040 .000 \\
\hline 2011 & 960 \\
\hline 2012 & 809 \\
\hline 2013 & 655 \\
\hline 2014 & 453 \\
\hline 2015 & 243 \\
\hline 2016 & 155 \\
\hline 2017 & 144 \\
\hline Total & 7.969 .000 \\
\hline
\end{tabular}

Table 3: The bibliometrics in biosensor and diagnosis in câncer (2007-2017).

\begin{tabular}{|c|c|c|c|}
\hline Year & Diagnosis & Cancer & RI (\%) \\
\hline 2007 & 2.24 & 1.240 .000 & 0.181 \\
\hline 2008 & 3.8 & 1.180 .000 & 0.322 \\
\hline 2009 & 5.95 & 1.090 .000 & 0.556 \\
\hline 2010 & 6.34 & 1.040 .000 & 0.61 \\
\hline 2011 & 4.59 & 960 & 0.478 \\
\hline 2012 & 5.56 & 809 & 0.687 \\
\hline 2013 & 6.24 & 655 & 0.953 \\
\hline 2014 & 7.1 & 453 & 1.567 \\
\hline 2015 & 8.06 & 243 & 3.317 \\
\hline 2016 & 8.66 & 155 & 5.587 \\
\hline 2017 & 9.54 & 144 & 6.625 \\
\hline
\end{tabular}

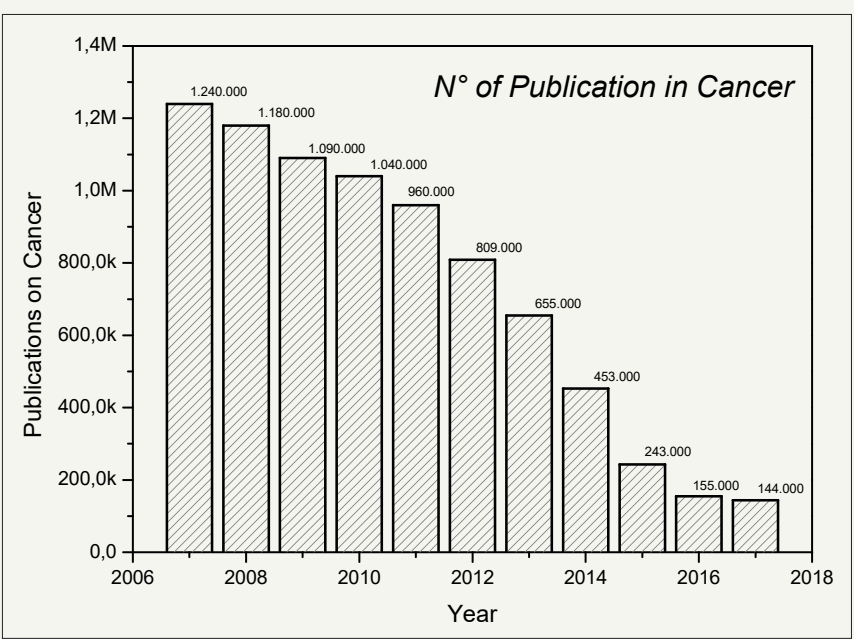

Figure 1: The decrease of publications in cancer (2007-2017). 


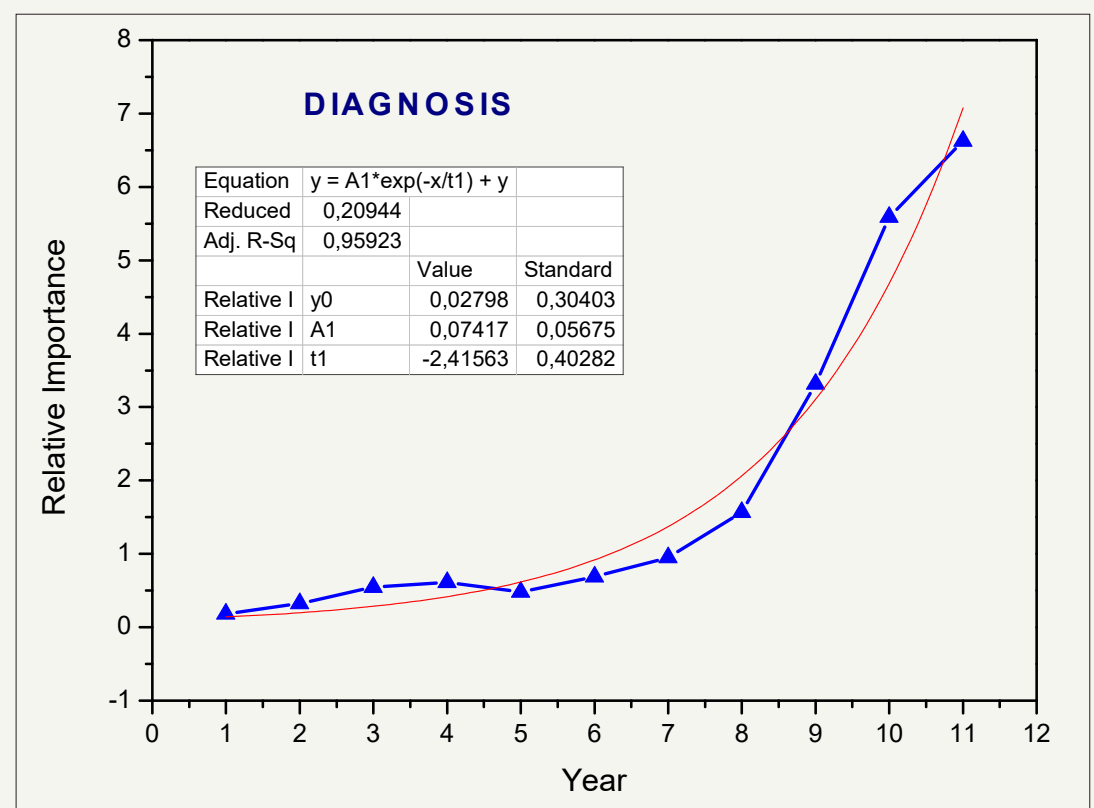

Figure 2: The Relative Importance and Tendency Curve in biosensor and diagnosis in cancer (2007-2017).

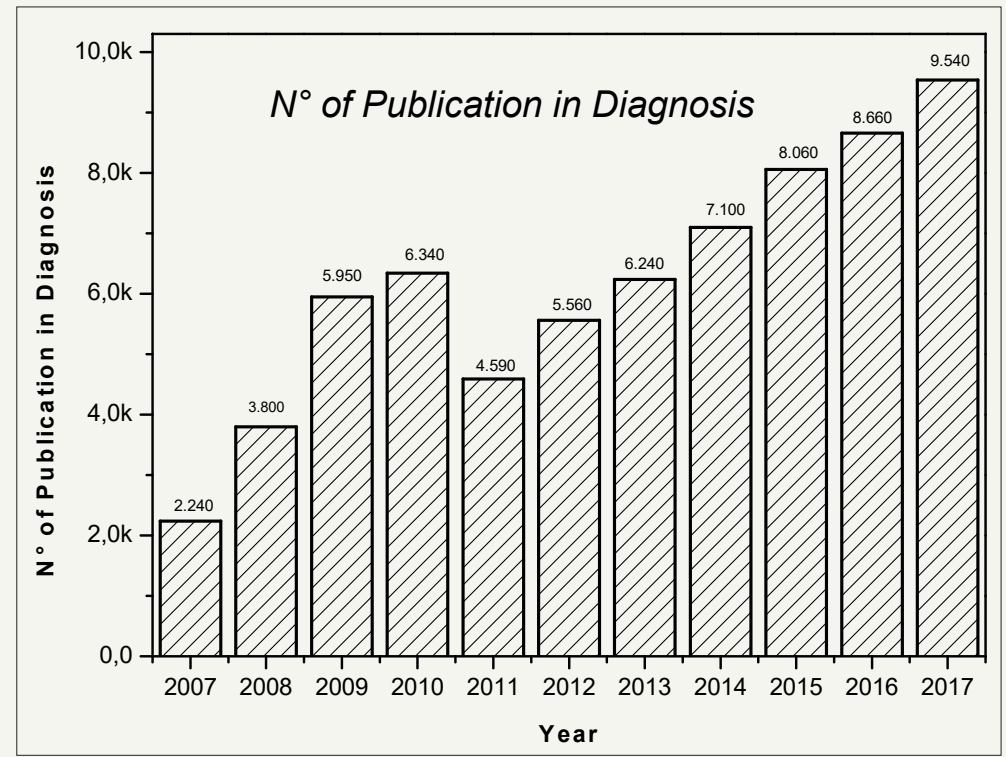

Figure 3: The increase of publications in biosensor and diagnosis in câncer (2007-2017)

Figure 3 shows the growth in the number of publications regarding the use of diagnostic biosensors in cancer. In 2007 there were equal to $2.24 \mathrm{~K}$ publications; in 2017, the number of publications was of $9.54 \mathrm{~K}$. Between 2010 and 2011 there was a decrease in the number of publications, but after 2012 the growth of publications took place again, evidencing an interest in research using biosensors for diagnosis in cancer.

Table 4: The bibliometrics in biosensor and biodetection in cancer in the last decade.

\begin{tabular}{|c|c|c|c|}
\hline Year & Biodetection & Cancer & RI (\%) \\
\hline 2007 & 170 & 1.240 .000 & 0.014 \\
\hline 2008 & 219 & 1.180 .000 & 0.018 \\
\hline
\end{tabular}

\begin{tabular}{|l|c|c|c|}
\hline 2009 & 246 & 1.090 .000 & 0.023 \\
\hline 2010 & 334 & 1.040 .000 & 0.032 \\
\hline 2011 & 357 & 960 & 0.037 \\
\hline 2012 & 398 & 809 & 0.049 \\
\hline 2013 & 464 & 655 & 0.071 \\
\hline 2014 & 563 & 453 & 0.124 \\
\hline 2015 & 588 & 243 & 0.242 \\
\hline 2016 & 552 & 155 & 0.356 \\
\hline 2017 & 683 & 144 & 0.474 \\
\hline
\end{tabular}

In cancer, the relative importance of publications in biosensors and bio-detection was of $0.013 \%$ in 2007 . Over the past few years, 
Relative Importance has increased. In 2017, its approximate value was $0.47 \%$, showing that research on biosensor tumor markers using biosensors are increasing. This increase can be observed in Table 4 and Figure 4. Figure 5 shows the increase in the number of publications in biodetection in the last decade. The relative importance of biosensor and biomarker publications in cancer has increased in the last decade. In 2007, $0.078 \%$ of the publications in tuberculosis were directly related to biosensors and biomarker; in 2017, this value was of $4.49 \%$. Table 5 and Figure 6 show the treated data. Figure 7 shows the number of publications in the last decade of the use of biosensors as a biomarker in cancer.

Table 5: The bibliometrics of biosensor and biomarker in cancer (2007-2017).

\begin{tabular}{|c|c|c|c|}
\hline Year & Biomarker & Cancer & RI (\%) \\
\hline 2007 & 970 & 1.240 .000 & 0.782 \\
\hline
\end{tabular}

\begin{tabular}{|l|l|l|l|}
\hline 2008 & 1.21 & 1.180 .000 & 0.103 \\
\hline 2009 & 1.6 & 1.090 .000 & 0.147 \\
\hline 2010 & 1.99 & 1.040 .000 & 0.191 \\
\hline 2011 & 2.52 & 960 & 0.263 \\
\hline 2012 & 3.07 & 809 & 0.379 \\
\hline 2013 & 3.65 & 655 & 0.557 \\
\hline 2014 & 4.28 & 453 & 0.945 \\
\hline 2015 & 4.91 & 243 & 2.021 \\
\hline 2016 & 5.69 & 155 & 3.671 \\
\hline 2017 & 6.47 & 144 & 4.493 \\
\hline
\end{tabular}

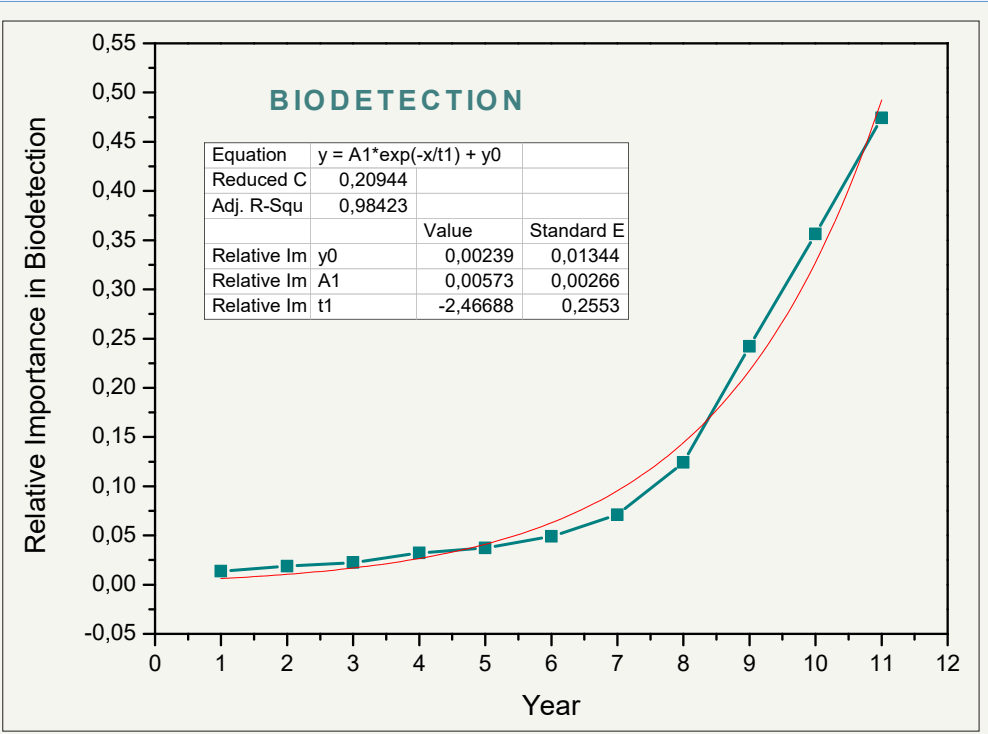

Figure 4: The Relative Importance and Tendency Curve in biosensor and biodetection in cancer in the last decade.

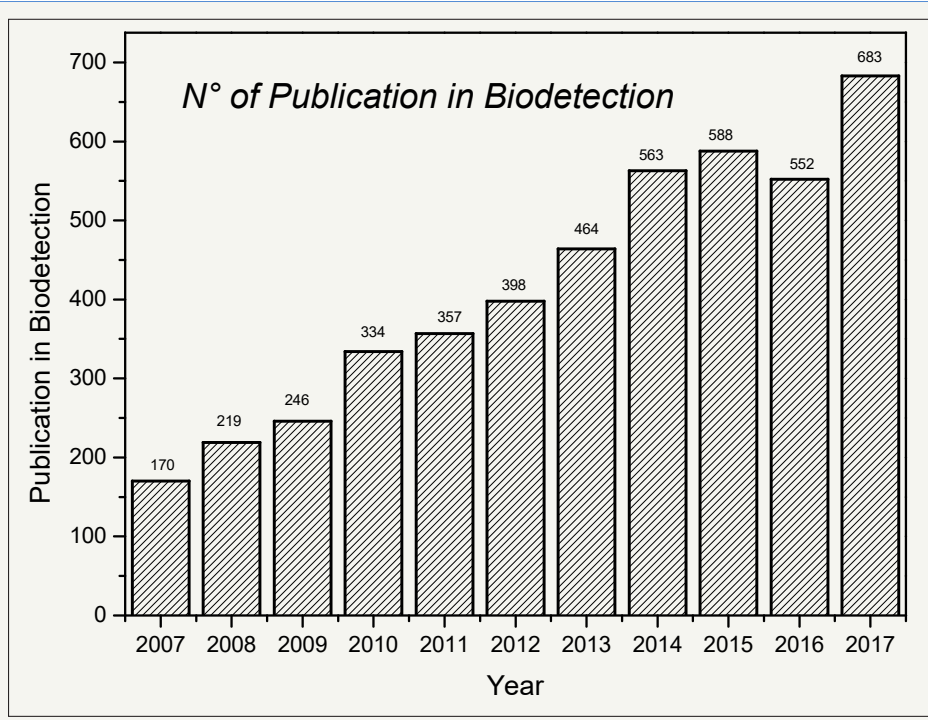

Figure 5: The bibliometrics of biodetection in cancer using biosensors in the last decade. 


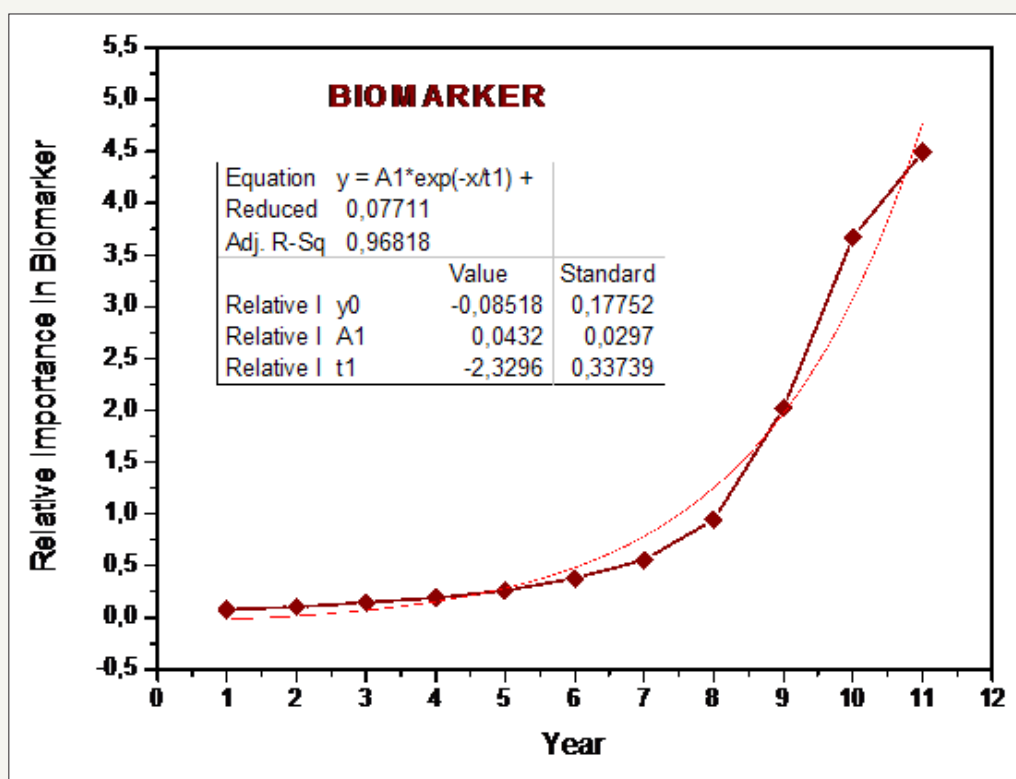

Figure 6: The Relative Importance and Tendency Curve in biosensor and biomarker in cancer in the last decade.

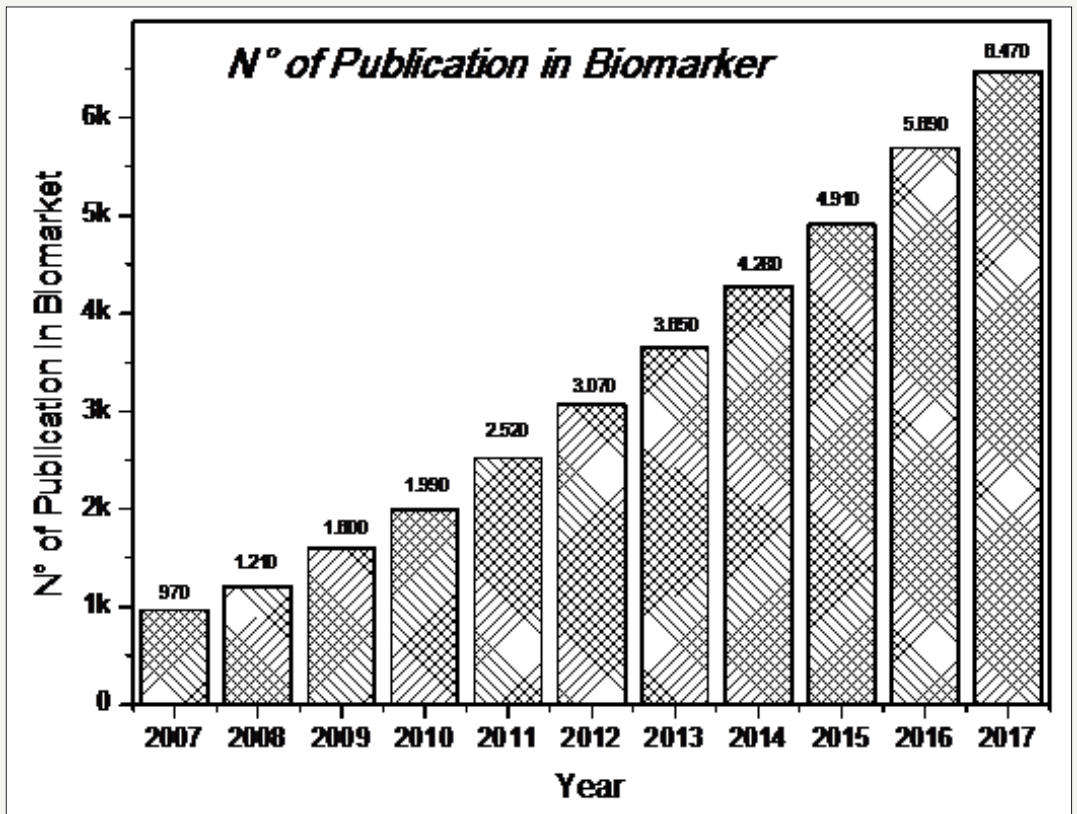

Figure 7: The bibliometrics of biosensor and biomarker in cancer in the last decade.

The Relative Importance of biosensor publications and cancer prevention has increased in the last decade. In 2007, 0.11\% of cancer publications were directly related to biosensors and prevention; in 2017, this value was of 3.86\%. Table 6 and Figure 8 show the treated data. Figure 9 shows the number of publications of biosensor and prevention in cancer in the last decade

Table 6: The bibliometrics of biosensor and prevention of cancer in the last decade.

\begin{tabular}{|c|c|c|c|}
\hline Year & Prevention & Cancer & RI (\%) \\
\hline 2007 & 1.41 & 1.240 .000 & 0.114 \\
\hline 2008 & 1.64 & 1.180 .000 & 0.139 \\
\hline
\end{tabular}

\begin{tabular}{|l|c|c|c|}
\hline 2009 & 2.49 & 1.090 .000 & 0.229 \\
\hline 2010 & 2.84 & 1.040 .000 & 0.273 \\
\hline 2011 & 2.82 & 960 & 0.294 \\
\hline 2.012 & 3.41 & 809 & 0.421 \\
\hline 2013 & 3.87 & 655 & 0.591 \\
\hline 2014 & 4.27 & 453 & 0.943 \\
\hline 2015 & 4.93 & 243 & 2.029 \\
\hline 2016 & 5.02 & 155 & 3.239 \\
\hline 2017 & 5.57 & 144 & 3.868 \\
\hline
\end{tabular}




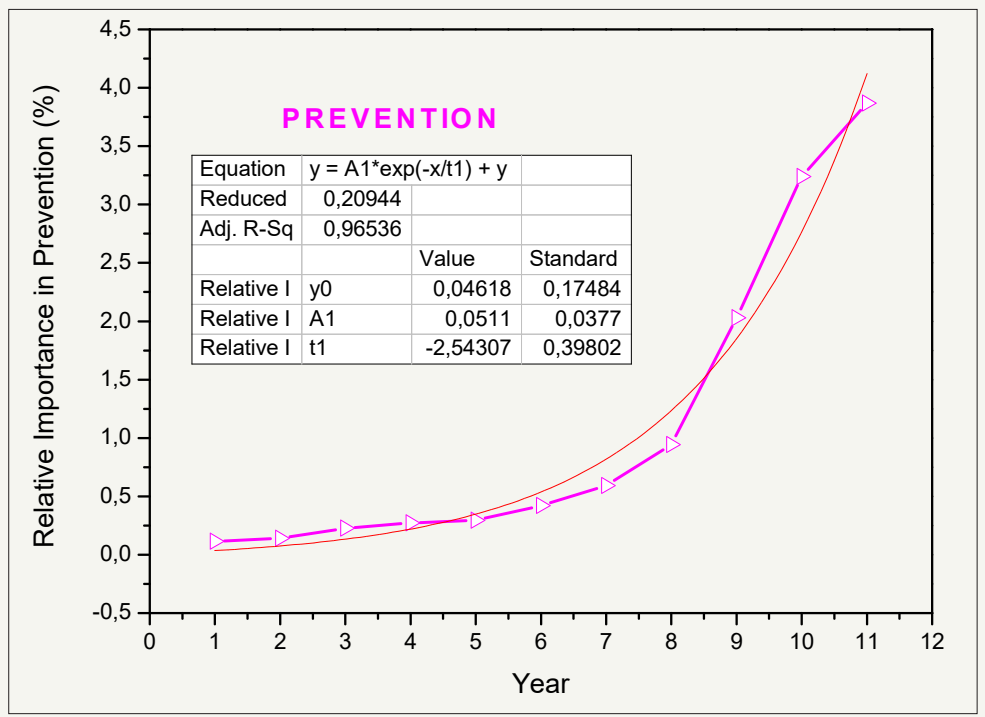

Figure 8: The Relative Importance and Tendency Curve using biosensor for prevention in cancer in the last decade.

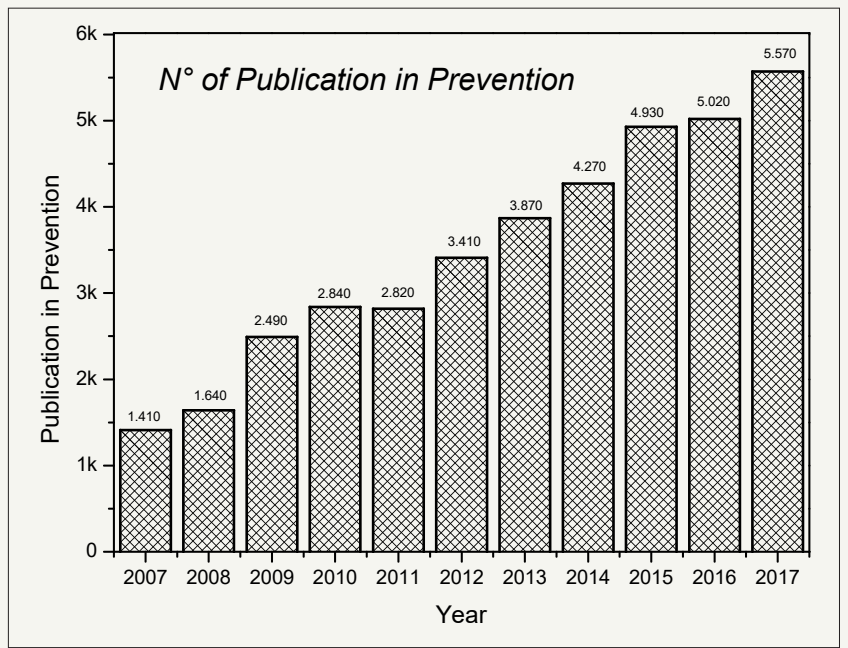

Figure 9: The bibliometrics of publications of biosensor and prevention of cancer in the last decade.

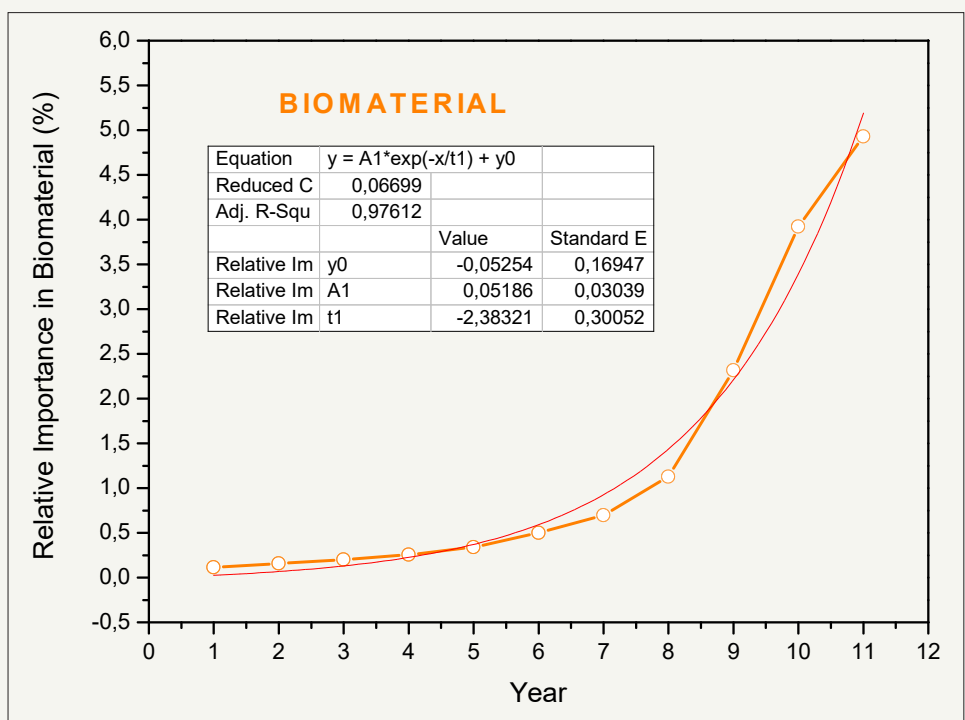

Figure 10: The Relative Importance and Tendency Curve of biosensor and biomaterial in cancer in the last decade. 
Table 7: The bibliometrics of biosensor and biomaterial in cancer in the last decade.

\begin{tabular}{|c|c|c|c|}
\hline Year & Biomaterial & Cancer & RI (\%) \\
\hline 2007 & 1.39 & 1.240 .000 & 0.112 \\
\hline 2008 & 1.86 & 1.180 .000 & 0.158 \\
\hline 2009 & 2.2 & 1.090 .000 & 0.202 \\
\hline 2010 & 2.66 & 1.040 .000 & 0.256 \\
\hline 2011 & 3.27 & 960 & 0.341 \\
\hline 2012 & 4.05 & 809 & 0.501 \\
\hline 2013 & 4.57 & 655 & 0.698 \\
\hline 2014 & 5.11 & 453 & 1.128 \\
\hline 2015 & 5.63 & 243 & 2.317 \\
\hline 2016 & 6.08 & 155 & 3.923 \\
\hline 2017 & 7.1 & 144 & 4.931 \\
\hline
\end{tabular}

The relative importance of biosensor and biomaterial publications in cancer has increased in the last decade. In 2007, $0.11 \%$ of cancer publications were directly related to biosensors and biomaterials; in 2017, this value was of $4.93 \%$. Table 7 shows these values during the last decade, while Figure 10 presents the tendency line, the value of $\mathrm{R}^{2}$, as well as the Relative Importance.

The number of publications about biosensors and biomaterials in cancer has increased over the last decade, as can be seen in Figure 11. In 2007, there were $1.39 \mathrm{~K}$ publications; in 2017, the number increased reaching $7.10 \mathrm{~K}$ publications. The relative importance of publications of biosensors and nanoparticles in cancer has increased in the last decade. In 2007, $0.13 \%$ of cancer publications were directly related to biosensors and nanoparticles; in 2017, this value was of $7.77 \%$. Table 8 and Figure 12 show the treated data. The number of publications on biosensors and nanoparticles in cancer has increased over the last decade, as can be seen in Figure 13. In 2007, the number of publications was equal to $1.69 \mathrm{~K}$ publications; in 2017 , the number reached $11.20 \mathrm{~K}$ publications.

Table 8: The bibliometrics of biosensors using nanoparticles in cancer in the last decade.

\begin{tabular}{|c|c|c|c|}
\hline Year & Nanoparticles & Cancer & RI (\%) \\
\hline 2007 & 1.69 & 1.240 .000 & 0.136 \\
\hline 2008 & 2.29 & 1.180 .000 & 0.194 \\
\hline 2009 & 2.88 & 1.090 .000 & 0.264 \\
\hline 2010 & 3.67 & 1.040 .000 & 0.353 \\
\hline 2011 & 4.5 & 960 & 0.469 \\
\hline
\end{tabular}

\begin{tabular}{|l|l|l|l|}
\hline 2012 & 5.62 & 809 & 0.695 \\
\hline 2013 & 6.61 & 655 & 1.009 \\
\hline 2014 & 7.51 & 453 & 1.658 \\
\hline 2015 & 8.76 & 243 & 3.605 \\
\hline 2016 & 9.63 & 155 & 6.213 \\
\hline 2017 & 11.2 & 144 & 7.778 \\
\hline
\end{tabular}

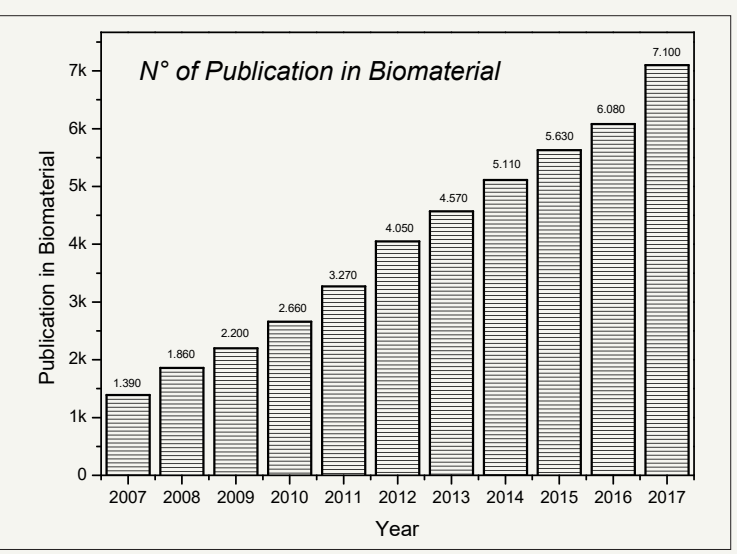

Figure 11: The bibliometrics of biosensor using biomaterial in cancer in the last decade.

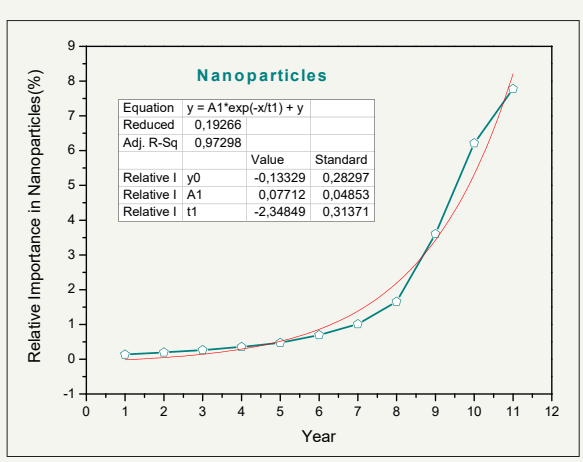

Figure 12: The Relative Importance and Tendency Curve of the biosensor using nanoparticles in cancer in the last decade.

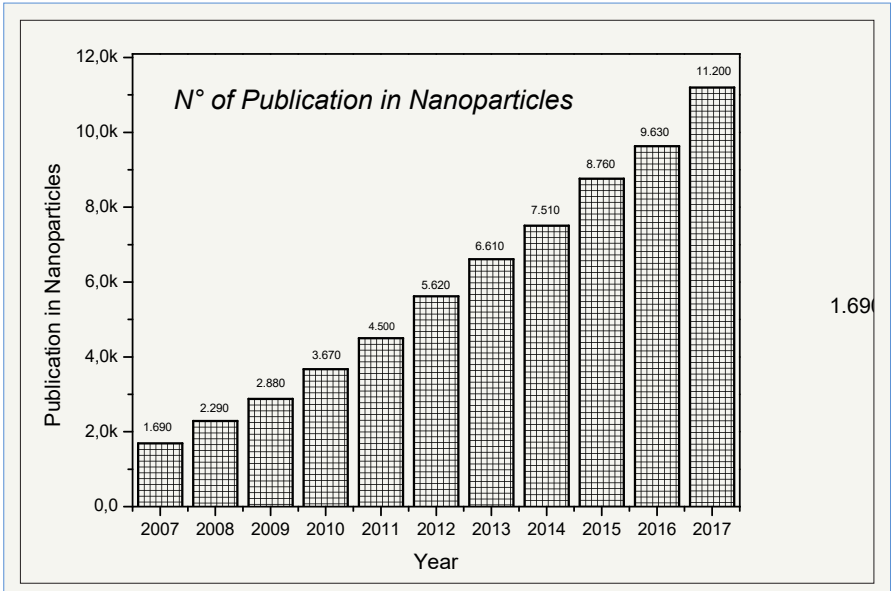

Figure 13: The bibliometrics of biosensor and nanoparticles in cancer in the last decade. 
The relative importance of publications of biosensors and graphene in cancer has increased in the last decade. In 2007, 0.01\% of cancer publications were directly related to biosensors and graphene; in 2017, this value was of 3.99\%. Table 9 and Figure 14 show the treated data. The Relative Importance of biosensor and tattoos publications on cancer has increased in the last decade. In $2007,0.001 \%$ of cancer publications were directly related to biosensors and tattoos; in 2017, this value was of $0.07 \%$. Table 10 shows these values during the last decade; and in Figure 15 it is possible to observe the tendency line, the value of $\mathrm{R}^{2}$, as well as the Relative Importance. The number of publications on biosensors and tattoos in cancer has increased over the last decade, as can be seen in Figure 16.

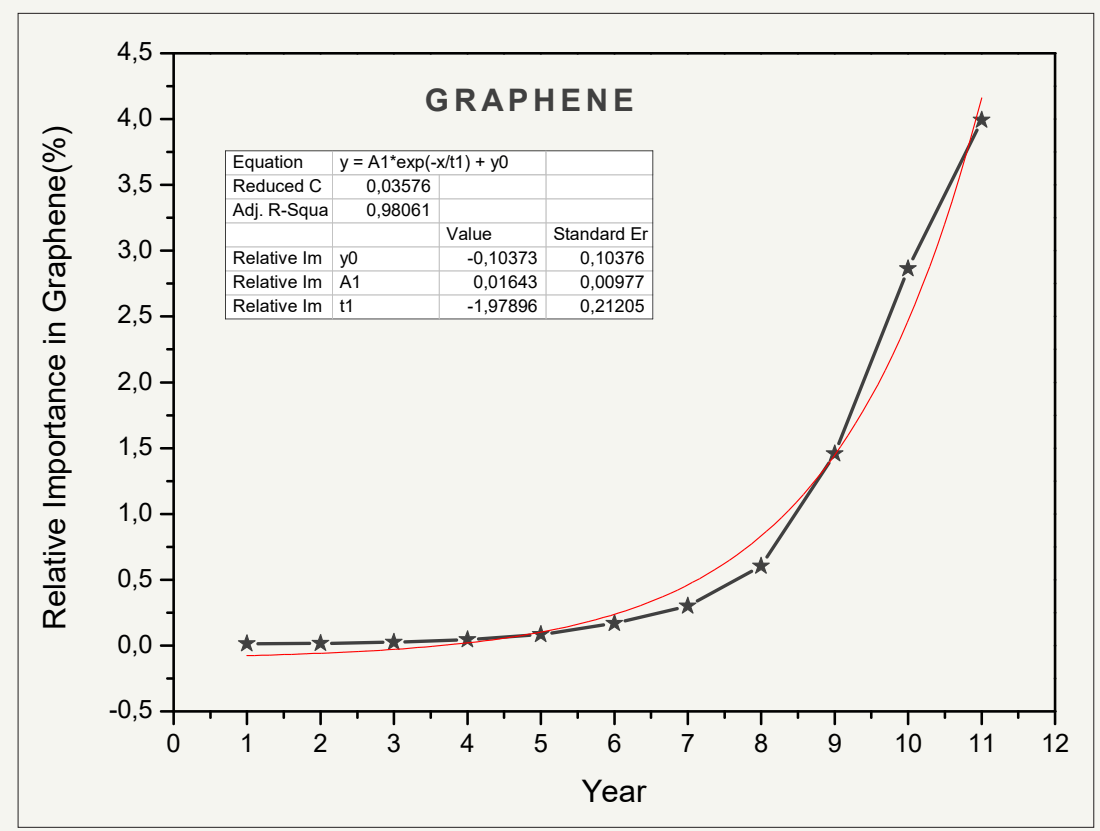

Figure 14: The Relative Importance and Tendency Curve of biosensors using graphene in cancer in the last decade.

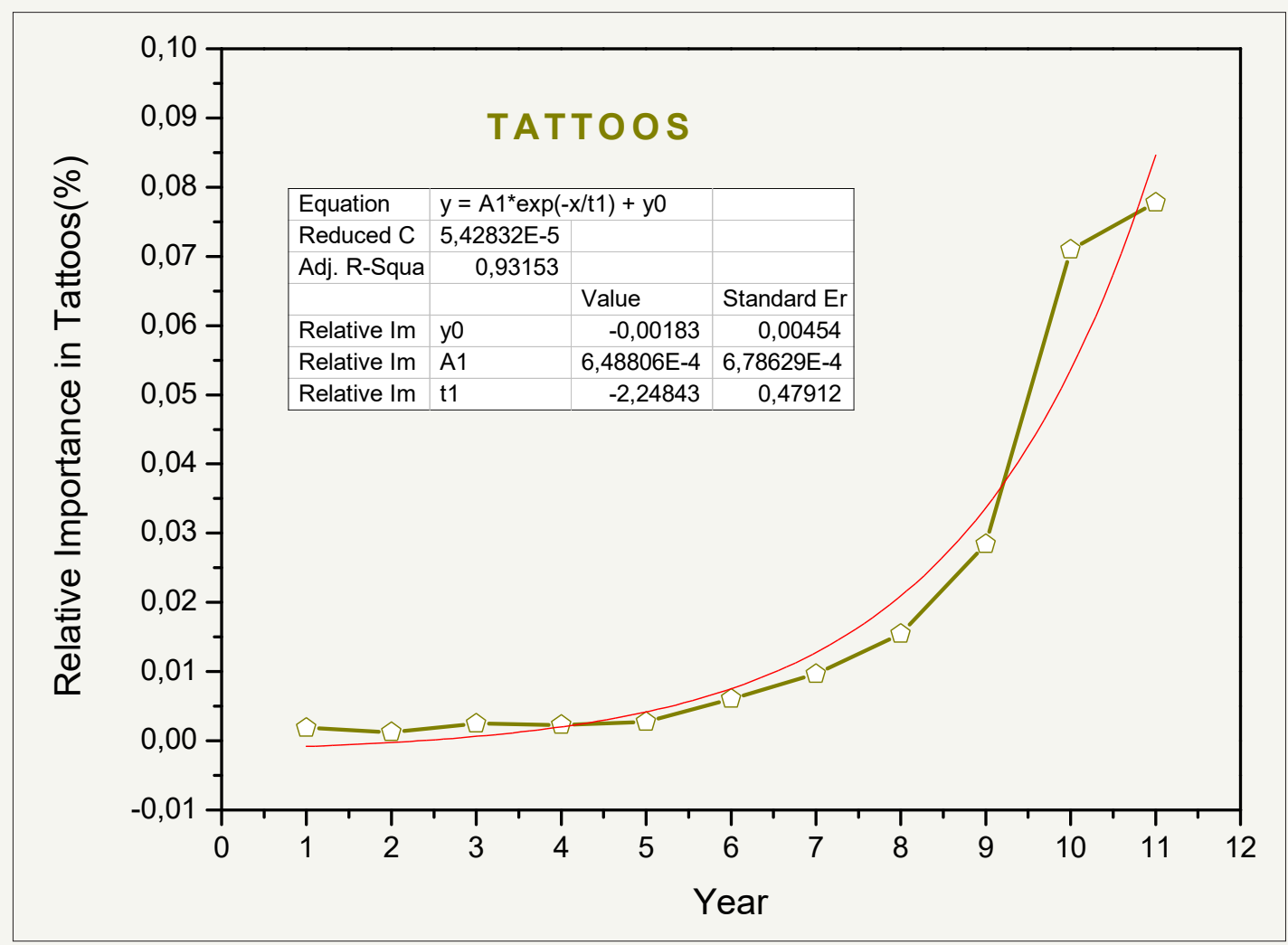

Figure 15: The Relative Importance and Tendency Curve of the biosensor used in tattoos in cancer. 


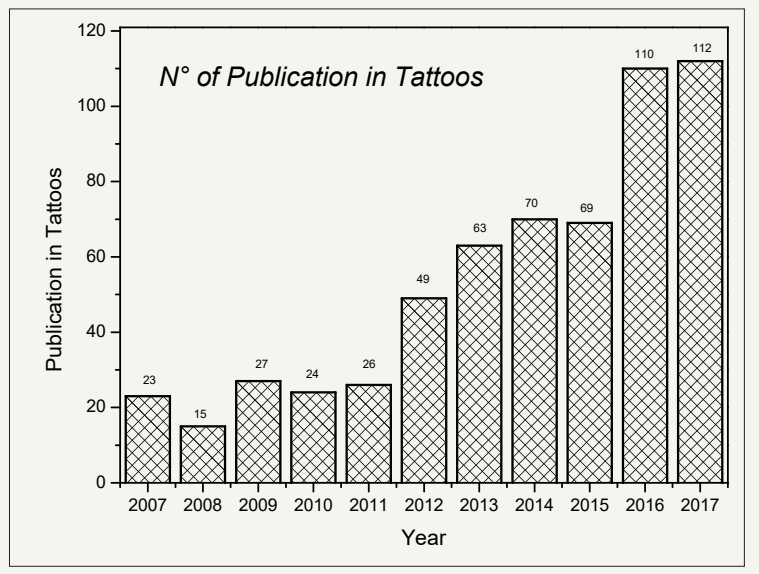

Figure 16: The bibliometrics of biosensor and tattoos in cancer in the last decade.

Table 9: The bibliometrics of the biosensor using graphene in cancer in the last decade.

\begin{tabular}{|c|c|c|c|}
\hline Year & Graphene & Cancer & RI (\%) \\
\hline 2007 & 155 & 1.240 .000 & 0.013 \\
\hline 2008 & 190 & 1.180 .000 & 0.016 \\
\hline 2009 & 281 & 1.090 .000 & 0.026 \\
\hline 2010 & 461 & 1.040 .000 & 0.044 \\
\hline 2011 & 801 & 960 & 0.083 \\
\hline 2012 & 1.35 & 809 & 0.167 \\
\hline 2013 & 1.96 & 655 & 0.299 \\
\hline 2014 & 2.73 & 453 & 0.603 \\
\hline 2015 & 3.54 & 243 & 1.457 \\
\hline 2016 & 4.44 & 155 & 2.865 \\
\hline 2017 & 5.75 & 144 & 3.993 \\
\hline
\end{tabular}

Table 10: The bibliometrics of biosensor using tattoos in cancer in the last decade.

\begin{tabular}{|c|c|c|c|}
\hline Year & Tattoos & Cancer & RI \% \\
\hline 2007 & 23 & 1.240 .000 & 0.002 \\
\hline 2008 & 15 & 1.180 .000 & 0.001 \\
\hline 2009 & 27 & 1.090 .000 & 0.002 \\
\hline 2010 & 24 & 1.040 .000 & 0.002 \\
\hline 2011 & 26 & 960 & 0.003 \\
\hline 2012 & 49 & 809 & 0.006 \\
\hline 2013 & 63 & 655 & 0.01 \\
\hline 2014 & 70 & 453 & 0.015 \\
\hline 2015 & 69 & 243 & 0.028 \\
\hline 2016 & 110 & 155 & 0.071 \\
\hline 2017 & 112 & 144 & 0.078 \\
\hline
\end{tabular}

The relative importance of biosensor and point-of-care (POC) publications in cancer has increased in the last decade. In 2007, $0.02 \%$ of cancer publications were directly related to biosensors and POCs; in 2017, this value was of $1.77 \%$. Table 11 shows these values during the last decade; and in Figure 17 it is possible to observe the tendency line, the value of $\mathrm{R}^{2}$, as well as Relative Importance. The number of publications on biosensors and Pointof-care in cancer has increased over the last decade, as can be seen in Figure 18.

Table 11: The bibliometrics of biosensor Point-of-care in cancer.

\begin{tabular}{|c|c|c|c|}
\hline Year & Point-of-Care & Cancer & RI (\%) \\
\hline 2007 & 300 & 1.240 .000 & 0.024 \\
\hline 2008 & 387 & 1.180 .000 & 0.033 \\
\hline 2009 & 513 & 1.090 .000 & 0.047 \\
\hline 2010 & 686 & 1.040 .000 & 0.066 \\
\hline 2011 & 828 & 960 & 0.086 \\
\hline 2012 & 1.05 & 809 & 0.13 \\
\hline 2013 & 1.27 & 655 & 0.194 \\
\hline 2014 & 1.62 & 453 & 0.358 \\
\hline 2015 & 1.91 & 243 & 0.786 \\
\hline 2016 & 2.21 & 155 & 1.426 \\
\hline 2017 & 2.55 & 144 & 1.771 \\
\hline
\end{tabular}

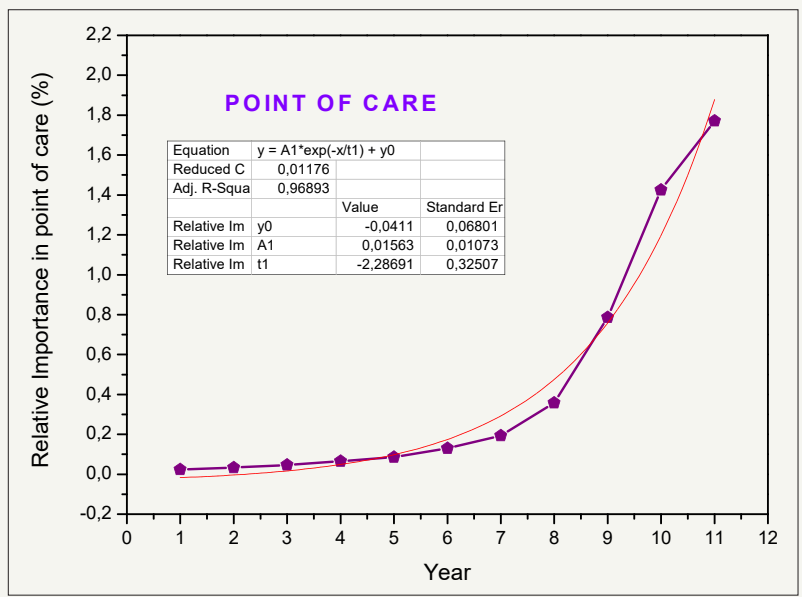

Figure 17: The Relative Importance and Tendency Curve of biosensor and Point-of-care in cancer. 


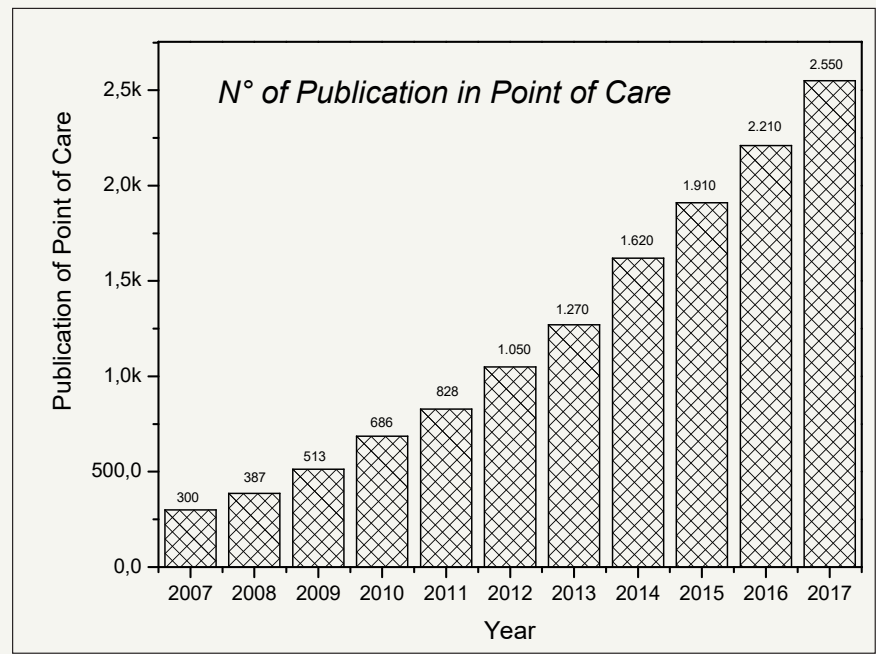

Figure 18: The bibliometrics of biosensor and Point-of-care in cancer in the last decade.

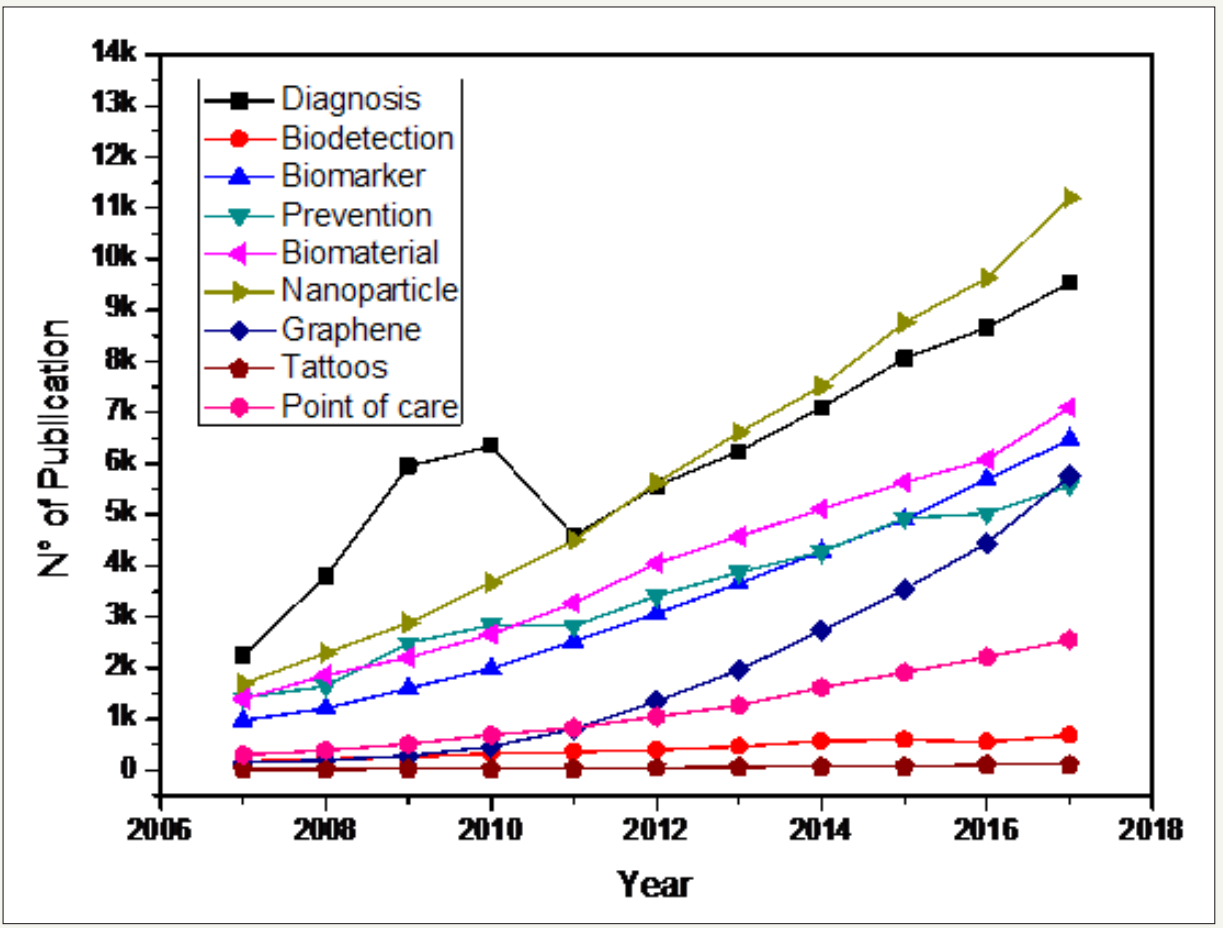

Figure 19: Comparison of the number of biosensor publications in the cancer applications that this study considered.

Figure 19 shows a comparison of the number of biosensor publications in the cancer applications that this study considered. Despite the more significant number of publications being diagnosed, it can be observed that the number of publications in the year 2017 using nanoparticles in cancer was higher than in diagnosis. The second highest number of applications was diagnosed, followed by biomaterial, biomarker, prevention, graphene, point-of-care, bio-detection, and tattoo, respectively. Some factors may have contributed to the decline of bibliometrics in cancer. One such factor was the global crisis that occurred in the period from 2008 to 2013, which directly affected investment in $\mathrm{R}$ \& D in several countries around the world, as shown in a study by OECD [146].
Although the fall in investment may have directly affected cancer research, it has been observed that concerning nanotechnology, the bibliometrics in cancer biosensors have increased considerably, evidencing a trend in new technologies applied to medicine.

Figure 20 shows the values of the relative importance of biosensor applications in cancer. As can be observed, the use of nanoparticles in the year 2016 and 2017 has become the largest of all applications, followed by diagnosis, biomaterial, biomarker, graphene, prevention, point-of-care, bio-detection, and tattoos. As it was shown throughout this work, all the curves of tendency had behavior that corresponds to the increase of the publications using biosensors in cancer, confirming, thus, a tendency in the use of the same one. 


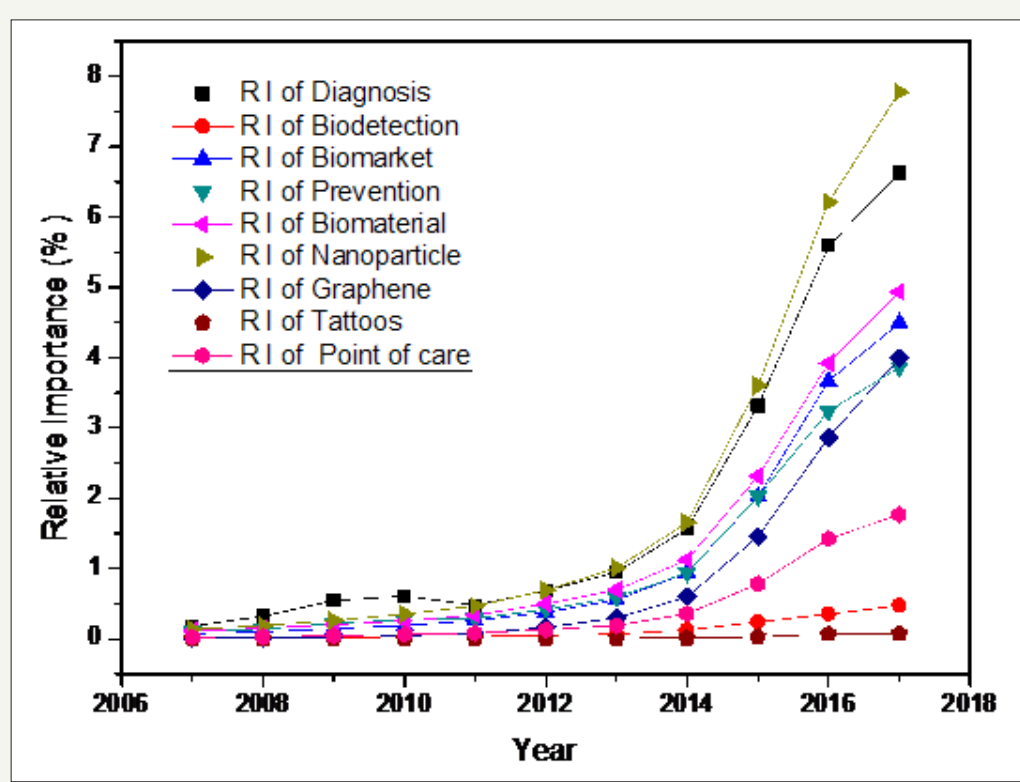

Figure 20: The values of Relative Importance in the last decade of biosensor applications in cancer.

\section{Conclusion}

The use of biosensors has been growing over the last decade, evidencing a search for new applications in it. However, despite significant budget cuts in R \& D, this seems to have not affected the use of biosensors and their diverse applications in cancer, showing that the use of technologies applied to health, such as medicine, is a trend in clinical research.

\section{Acknowledgement}

The authors thank Conselho Nacional de Desenvolvimento Científico e Tecnológico, Coordenação de Aperfeiçoamento de Pessoal de Nível Superior (CAPES), Financiadora de Estudos e Projetos (FINEP PRESAL Ref.1889/10), and Fundação Carlos Chagas Filho de Amparo à Pesquisa do Estado do Rio de Janeiro (FAPERJ) for the financial support and scholarships.

\section{References}

1. Zhang N, Luo Y, He L, Zhou L, Wu W (2016) A self-assembly peptide nanofibrous scaffold reduces inflammatory response and promotes functional recovery in a mouse model of intracerebral hemorrhage. Nanomedicine 12(5): 1205-1217.

2. Badri Narayanan KNS (2010) Biological synthesis of metal nanoparticles by microbes. Adv Colloid Interface Sci 156(1-2): 1-13.

3. Al Jamal WT, Kostarelos K (2011) Liposomes: from a clinically established drug delivery system to a nanoparticle platform for theranostic nanomedicine. Acc Chem Res 44(10): 1094-104.

4. Bhattacharyya AS, Hasan JR, Adeyemi MM, Marye MM, Raja Naika H (2015) Nanotechnology-a unique future technology in aquaculture for the food security. Int J Bioassays 4: 4115-4126.

5. Parveen S, Misra R, Sahoo SK (2012) Nanoparticles: a boon to drug delivery, therapeutics, diagnostics and imaging. Nanomedicine Nanotechnol Biol Med 8(2): 147-166.

6. Couvreur P, Vauthier C (2006) Nanotechnology: intelligent design to treat complex disease. Pharm Res 23(7): 1417-1450.
7. Wang L, Xiong Q, Xiao F, Duan H (2017) 2D nanomaterials based electrochemical biosensors for cancer diagnosis. Biosens Bioelectron 89(pt1): 136-151.

8. Kerbel RS (1997) A cancer therapy resistant to resistance. Nature 390: 335-336.

9. Restifo NP, Dudley ME, Rosenberg SA (2012) Adoptive immunotherapy for cancer: harnessing the T cell response. Nat Rev Immunol 12(4): 269281.

10. Huang P, Wang D, Su, Y, Huang W, Zhou Y, et al. (2014) Combination of small molecule prodrug and nanodrug delivery: amphiphilic drug-drug conjugate for cancer therapy. J Am Chem Soc 136: 11748-11756.

11. Song HS, Kwon OS, Kim JH, Conde J, Artzi N (2017) 3D hydrogel scaffold doped with 2D graphene materials for biosensors and bioelectronics. Biosens Bioelectron 89(pt1): 187-200.

12. Campos BD, Konradsson G, Quintero JE, Marshall L (2018) Amperometric self-referencing ceramic-based microelectrode arrays for d-serine detection. Biosensors 8(1): E20.

13. Xu M, Wang R, Li Y (2017) Electrochemical biosensors for rapid detection of Escherichia coli 0157:H7. Talanta 162: 511-522.

14. Jin H, Gui R, Yu J, Lv W, Wang Z (2017) Fabrication strategies, sensing modes and analytical applications of ratiometric electrochemical biosensors. Biosens Bioelectron 91: 523-537.

15. Lin ZT, De Marr V, Bao J, Wu T (2018) Molecularly imprinted polymerbased biosensors: For the early, rapid detection of pathogens, biomarkers, and toxins in clinical, environmental, or food samples. IEEE Nanotechnol Mag 12(1): 6-13.

16. Șeker E, Shih WC, Stine KJ (2018) Nanoporous metals by alloy corrosion: Bioanalytical and biomedical applications. MRS Bull 43(1): 49-56.

17. Saffer EM, Tew GN, Bhatia SR (2011) Poly(lactic acid)-poly(ethylene oxide) block copolymers: new directions in self-assembly and biomedical applications. Curr Med Chem 18(36): 5676-5686.

18. Khan A, Khan AAP, Asiri AM, Khan SA, Khan I, et al. (2018) Polymerinorganic nanocomposite and biosensors. Electr Conduct Polym Polym Compos Synth Biomed Appl 247.

19. Chambers JP, Arulanandam BP, Matta LL, Weis A, Valdes JJ (2008) Biosensor recognition elements. Curr Issues Mol Biol 10(1-2): 1-12. 
20. Dai Y, Molazemhosseini A, Liu CC (2017) A single-use, in vitro biosensor for the detection of T-tau protein, a biomarker of neuro-degenerative disorders, in PBS and human serum using differential pulse voltammetry (DPV). Biosensors 7(1): E10.

21. Ahmed M, Carrascosa LG, Sina AAI, Zarate EM, Korbie D, et al. (2017) Detection of aberrant protein phosphorylation in cancer using direct gold-protein affinity interactions. Biosens Bioelectron 91: 8-14.

22. Wang SX, Acha D, Shah AJ, Hills F, Roitt I, et al. (2017) Detection of the tau protein in human serum by a sensitive four-electrode electrochemical biosensor. Biosens Bioelectron 92: 482-488.

23. Conley JM, Radhakrishnan S, Valentino SA, Tantama MC (2017) Development and characterization of a fluorescent protein-based biosensor for the detection of extracellular ATP. FASEB J 31(1): 828-825.

24. Jiang $X$, Wang $H$, Wang H, Zhuo $Y$, Yuan R, et al. (2017) Electrochemiluminescence biosensor based on 3-D DNA nanomachine signal probe powered by protein-aptamer binding complex for ultrasensitive mucin 1 Detection. Anal Chem 89(7): 4280-4286.

25. Song J, Dailey J, Li H, Jang HJ, Zhang P, et al. (2017) Extended solution gate ofet-based biosensor for label-free glial fibrillary acidic protein detection with polyethylene glycol-containing bioreceptor layer. Adv Funct Mater 27(20).

26. Zhang X, Yang S, Jiang R, Sun L, Pang S, et al. (2018) Fluorescent molecularly imprinted membranes as biosensor for the detection of target protein. Sens Actuators B Chem 254: 1078-1086.

27. Wang H, Li Y, Zhao K, Chen S, Wang Q, et al. (2017) G-quadruplex-based fluorometric biosensor for label-free and homogenous detection of protein acetylation-related enzymes activities. Biosens Bioelectron 91: 400-407.

28. Zubiate P, Zamarreño CR, Sánchez P, Matias IR, Arregui FJ (2017) High sensitive and selective C-reactive protein detection by means of lossy mode resonance based optical fiber devices. Biosens Bioelectron 93: 176-181.

29. Hwang HJ, Ryu MY, Park CY, Ahn J, Park HG, et al. (2017) High sensitive and selective electrochemical biosensor: Label-free detection of human norovirus using affinity peptide as molecular binder. Biosens Bioelectron 87: $164-170$.

30. Li N, Chen J, Luo M, Chen C, Ji X, et al. (2017) Highly sensitive chemiluminescence biosensor for protein detection based on the functionalized magnetic microparticles and the hybridization chain reaction. Biosens Bioelectron 87: 325-331.

31. Jakob MH, Dong B, Gutsch S, Chatelle C, Krishnaraja A, et al. (2017) Labelfree $\mathrm{S}_{n} \mathrm{O}_{2}$ nanowire FET biosensor for protein detection. Nanotechnology 28(24): 245503

32. Lin D, Harris KD, Chan NW, Jemere AB (2018) Nanostructured indium tin oxide electrodes immobilized with toll-like receptor proteins for labelfree electrochemical detection of pathogen markers. Sens Actuators B Chem 257: 324-330.

33. Jayanthi VSA, Das AB, Saxena U (2017) Recent advances in biosensor development for the detection of cancer biomarkers. Biosens Bioelectron 91: 15-23.

34. Musameh MM, Dunn CJ, Uddin MH, Sutherland TD, Rapson TD (2018) Silk provides a new avenue for third generation biosensors: Sensitive, selective and stable electrochemical detection of nitric oxide. Biosens Bioelectron 103: 26-31.

35. Chiu NF, Kuo CT, Lin TL, Chang CC, Chen CY (2017) Ultra-high sensitivity of the non-immunological affinity of graphene oxide-peptide-based surface plasmon resonance biosensors to detect human chorionic gonadotropin. Biosens Bioelectron 94: 351-357.

36. Yang Y, Yang X, Zou X, Wu S, Wan D, et al. (2017) Ultrafine graphene nanomesh with large on/off ratio for high-performance flexible biosensors. Adv Funct Mater 27(19)
37. Tereshchenko A, Fedorenko V, Smyntyna V, Konup I, Konup A, et al. (2017) $\mathrm{Z}_{\mathrm{n}} \mathrm{O}$ films formed by atomic layer deposition as an optical biosensor platform for the detection of Grapevine virus A-type proteins. Biosens Bioelectron 92: 763-769.

38. Wasik D, Mulchandani A, Yates MV (2017) A heparin-functionalized carbon nanotube-based affinity biosensor for dengue virus. Biosens Bioelectron 91: 811-816.

39. Wong CL, Chua M, Mittman H, Choo LX, Lim HQ et al. (2017) A PhaseIntensity surface plasmon resonance biosensor for avian influenza a (H5N1) Detection. Sensors (Basel) 17(10): E2363.

40. Chang YF, Wang WH, Hong YW, Yuan RY, Chen KH, et al. (2018) A simple strategy for rapid and sensitive detection of avian influenza A H7N9 virus based on intensity-modulated SPR biosensor and new generated antibody. Anal Chem 90(3): 1861-1869.

41. Ahangar LE, Mehrgardi MA (2017) Amplified detection of hepatitis B virus using an electrochemical DNA biosensor on a nanoporous gold platform. Bioelectrochemistry 117: 83-88.

42. Khater M, De la Escosura Muñiz A, Merkoçi A (2017) Biosensors for plant pathogen detection. Biosens Bioelectron 93: 72-86.

43. Lai HC, Chin SF, Pang SC, Sum H, Sia M, et al. (2017) Carbon nanoparticles based electrochemical biosensor strip for detection of japanese encephalitis virus. J Nanomater 2017.

44. Fu Y, Romay V, Liu Y, Ibarlucea B, Baraban L, et al. (2017) Chemiresistive biosensors based on carbon nanotubes for label-free detection of DNA sequences derived from avian influenza virus H5N1. Sens Actuators B Chem 249: 691-699.

45. Kaushik A, Tiwari S, Jayant RD, Vashist A, Nikkhah MR, et al. (2017) Electrochemical biosensors for early stage Zika diagnostics. Trends Biotechnol 35(4): 308-317.

46. Sayhi M, Ouerghi O, Belgacem K, Arbi M, Tepeli Y, et al. (2018) Electrochemical detection of influenza virus H9N2 based on both immunomagnetic extraction and gold catalysis using an immobilizationfree screen-printed carbon microelectrode. Biosens Bioelectron 107: 170-177.

47. Mokhtarzadeh A, Eivazzadeh KR, Pashazadeh P, Hejazi M, Gharaatifar N, et al. (2017) Nanomaterial-based biosensors for detection of pathogenic virus. TrAC Trends Anal Chem 97: 445-457.

48. Chocarro RB, Fernández Gavela A, Herranz S, Lechuga LM (2017) Nanophotonic label-free biosensors for environmental monitoring. Curr Opin Biotechnol 45: 175-183.

49. Lee C, Wang P, Gaston MA, Weiss AA, Zhang P (2017) Plasmonics-Based detection of virus using sialic acid functionalized gold nanoparticles. Methods Mol Biol 1571: 109-116.

50. Wasik D, Mulchandani A, Yates MV (2017) Point-of-Use Nanobiosensor for detection of dengue virus ns1 antigen in adult aedes aegypti: a potential tool for improved dengue surveillance. Anal Chem 90(1): 679684.

51. Manzano M, Viezzi S, Mazerat S, Marks RS, Vidic J (2018) Rapid and label-free electrochemical DNA biosensor for detecting hepatitis A virus. Biosens Bioelectron 100: 89-95.

52. Anik Ü, Tepeli Y, Sayhi M, Nsiri J, Diouani MF (2018) Towards the electrochemical diagnostic of influenza virus: development of a graphene Au hybrid nanocomposite modified influenza virus biosensor based on neuraminidase activity. Analyst 143(1): 150-156.

53. Loughman T, Singh B, Seddon B, Noone P, Santhosh P (2017) Validation of a membrane touch biosensor for the qualitative detection of IgG class antibodies to herpes simplex virus type 2. Analyst 142(15): 2725-2734.

54. Takemura K, Adegoke O, Takahashi N, Kato T, Li TC, etal. (2017) Versatility of a localized surface plasmon resonance-based gold nanoparticlealloyed quantum dot Nano biosensor for immunofluorescence detection of viruses. Biosens Bioelectron 89(2): 998-1005. 
55. Pan Y, Zhan S, Xia F (2018) Zeolitic imidazolate framework-based biosensor for detection of HIV-1 DNA. Anal Biochem 546: 5-9.

56. Tereshchenko A, Fedorenko V, Smyntyna V, Konup I, Konup A, et al. (2017) ZnO films formed by atomic layer deposition as an optical biosensor platform for the detection of Grapevine virus A-type proteins. Biosensors and Bioelectronics 92: 763-769.

57. Wasik D, Mulchandani A, Yates MV (2017) A heparin-functionalized carbon nanotube-based affinity biosensor for dengue virus. Biosens Bioelectron 91: 811-816.

58. Guo X, Sang S, Guo J, Jian A, Duan Q, et al. (2017) A magneto elastic biosensor based on E2 glycoprotein for wireless detection of classical swine fever virus E2 antibody. Sci Rep 7: 15626.

59. Wong CL, Chua M, Mittman H, Choo LX, Lim HQ et al. (2017) A phaseintensity surface plasmon resonance biosensor for avian influenza A (H5N1) Detection. Sensors 17(10): E2363.

60. Chang YF, Wang WH, Hong YW, Yuan RY, Chen KH, et al. (2018) A simple strategy for rapid and sensitive detection of avian influenza A H7N9 virus based on intensity-modulated SPR biosensor and new generated antibody. Anal Chem 90(3): 1861-1869.

61. Vásquez G, Rey A, Rivera C, Iregui C, Orozco J (2017) Amperometric biosensor based on a single antibody of dual function for rapid detection of Streptococcus agalactiae. Biosens Bioelectron 87: 453-458.

62. Chen Q Huang F, Cai G, Wang M, Lin J (2018) An optical biosensor using immunomagnetic separation, urease catalysis and $\mathrm{pH}$ indication for rapid and sensitive detection of Listeria monocytogenes. Sens Actuators B Chem 258: 447-453.

63. Tubía I, Paredes J, Pérez Lorenzo, E, Arana S (2018) Antibody biosensors for spoilage yeast detection based on impedance spectroscopy. Biosens Bioelectron 102: 432-438.

64. Rubab M, Shahbaz HM, Olaimat AN, Oh DH (2018) Biosensors for rapid and sensitive detection of Staphylococcus aureus in food. Biosens Bioelectron 105: 49-57.

65. Rizzo R, Alvaro M, Danz N, Napione L, Descrovi E, et al. (2018) Bloch surface wave enhanced biosensor for the direct detection of Angiopoietin-2 tumor biomarker in human plasma. Biomed Opt Express 9(2): 529-542.

66. Palomar Q Gondran C, Holzinger M, Marks R, Cosnier S (2017) Controlled carbon nanotube layers for impedimetric immunosensors: High performance label free detection and quantification of anti-cholera toxin antibody. Biosens Bioelectron 97: 177-183.

67. Mavrikou S, Flampouri E, Iconomou D, Kintzios S (2017) Development of a cellular biosensor for the detection of aflatoxin B1, based on the interaction of membrane engineered Vero cells with anti-AFB1 antibodies on the surface of gold nanoparticle screen printed electrodes. Food Control 73: 64-70.

68. Yang X, Zhao Y, Sun L, Qi H, Gao Q et al. (2018) Electrogenerated chemiluminescence biosensor array for the detection of multiple AMI biomarkers. Sens and Actuators B Chem 257: 60-67.

69. Fattah ARA, Abdalla AM, Mishriki S, Meleca E, Geng F, et al. (2017) Magnetic printing of a biosensor: Inexpensive rapid sensing to detect picomolar amounts of antigen with antibody-functionalized carbon nanotubes. ACS Appl Mater Interfaces 9(13): 11790-11797.

70. Bazin I, Tria SA, Hayat A, Marty JL (2017) New biorecognition molecules in biosensors for the detection of toxins. Biosens and Bioelectron 87: 285-298.

71. Rodovalho VR, Araujo GR, Vaz ER, Ueira Vieira C, Goulart LR, et al. (2018) Peptide-based electrochemical biosensor for juvenile idiopathic arthritis detection. Biosens Bioelectron 100: 577-582.

72. Jayanthi VSA, Das AB, Saxena U (2017) Recent advances in biosensor development for the detection of cancer biomarkers. Biosens Bioelectron 91: 15-23.
73. Lan L, Yao Y, Ping J, Ying Y (2017) Recent advances in nanomaterialbased biosensors for antibiotics detection. Biosens Bioelectron 91: 504514.

74. Hu Y, Li H, Li J (2018) A novel electrochemical biosensor for HIV-related DNA detection based on toehold strand displacement reaction and cruciform DNA crystal. J Electroanal Chem 822: 66-72.

75. Tian S, Neumann O, McClain MJ, Yang X, Zhou L, et al. (2017) Aluminum nanocrystals: A sustainable substrate for quantitative SERS-based DNA detection. Nano Lett 17(8): 5071-5077.

76. Ariksoysal OD, Kayran YU, Yilmaz FF, Ciucu AA, David IG, et al. (2017) DNA-wrapped multi-walled carbon nanotube modified electrochemical biosensor for the detection of Escherichia coli from real samples. Talanta 166: $27-35$

77. Van Eeghem A, Werquin S, Hoste JW, Goes A, Vanderleyden E, et al. (2017) Double positive effect of adding hexamethylene glycol when optimizing the hybridization efficiency of a microring DNA detection assay. Appl Surf Sci 405: 321-328.

78. Yin H, Yang Z, Wang H, Zhou Y, Ai S (2017) Electrochemical biosensor for hydroxy methylated DNA detection and $\beta$-glucosyltransferase activity assay based on enzymatic catalysis triggering signal amplification. Sens Actuators B Chem 243: 602-608.

79. Teengam P, Siangproh W, Tuantranont A, Henry CS, Vilaivan T, et al. (2017) Electrochemical paper-based peptide nucleic acid biosensor for detecting human papillomavirus. Anal Chim Acta 952: 32-40.

80. Takalkar S, Baryeh K, Liu G (2017) Fluorescent carbon nanoparticlebased lateral flow biosensor for ultrasensitive detection of DNA. Biosens Bioelectron 98: 147-154.

81. Loan PTK, Wu D, Ye C, Li X, Tra VT, et al. (2018) Hall effect biosensors with ultraclean graphene film for improved sensitivity of label-free DNA detection. Biosens Bioelectron 99: 85-91.

82. Diao W, Tang M, Ding S, Li X, Cheng W, et al. (2018) Highly sensitive surface plasmon resonance biosensor for the detection of HIV-related DNA based on dynamic and structural DNA nanodevices. Biosens Bioelectron 100: 228-234.

83. Guo Y, Chen Q, Qi Y, Xie Y, Qian H, et al. (2017) Label-free ratio metric DNA detection using two kinds of interaction responsive emission dyes. Biosens Bioelectron 87: 320-324.

84. Huang CJ, Lin ZE, Yang YS, Chan HWH, Chen WY (2018) Neutralized chimeric DNA probe for detection of single nucleotide polymorphism on surface plasmon resonance biosensor. Biosens Bioelectron 99: 170-175.

85. Xu L, Xie S, Du J, He N (2017) Porous magnetic pseudo-carbon paste electrode electrochemical biosensor for DNA detection. I Nanosci Nanotechnol 17: 238-243.

86. Ensafi AA, Nasr Esfahani P, Rezaei B (2017) Quenching recovery fluorescent biosensor for DNA detection based on mercaptopropionic acid-capped cadmium telluride quantum dots aggregation. Sens Actuators B Chem 249: 149-155.

87. Liang SS, Qi L, Zhang RL, Jin M, Zhang ZQ (2017) Ratio metric fluorescence biosensor based on $\mathrm{Cd}$ Te quantum and carbon dots for double strand DNA detection. Sensors and Actuators B Chemical 244: 585-590.

88. Saidur MR, Aziz AA, Basirun WJ (2017) Recent advances in DNA based electrochemical biosensors for heavy metal ion detection: A review. Biosens Bioelectron 90: 125-139.

89. Shi XM, Fan GC, Tang X, Shen Q, Zhu JJ (2018) Ultrasensitive photoelectrochemical biosensor for the detection of HTLV-I DNA: A cascade signal amplification strategy integrating $\lambda$-exonuclease aided target recycling with hybridization chain reaction and enzyme catalysis. Biosens Bioelectron 109: 190-196.

90. Mao K, Yang Z, Li J, Zhou X, Li X, et al. (2017) A novel colorimetric biosensor based on non-aggregated Au@ Ag core-shell nanoparticles for methamphetamine and cocaine detection. Talanta 175: 338-346. 
91. Jabbari S, Dabirmanesh B, Arab SS, Amanlou M, Daneshjou S, et al. (2017) A novel enzyme based SPR-biosensor to detect bromocriptine as an ergoline derivative drug. Sensors and Actuators B Chemical 240: 519-527.

92. Hu L, Zou L, Qin Z, Fang J, Huang L, et al. (2017) A novel label-free bioengineered cell-based biosensor for salicin detection. Sensors and Actuators B Chemical 238: 1151-1158.

93. Evtugyn GA, Hianik T, Nikoleli GP, Nikolelis DP (2017) Biosensors for Detection of Neurotransmitters and Neurodegenerative Related Diseases. Front Clin Drug Res CNS Neurol Disord 5: 184.

94. Kurbanoglu S, Rivas L, Ozkan SA, Merkoçi A (2017) Electrochemically reduced graphene and iridium oxide nanoparticles for inhibition-based angiotensin converting enzyme inhibitor detection. Biosens Bioelectron 88: $122-129$

95. Wang H, Li Y, Zhao K, Chen S, Wang Q et al. (2017) G quadruplex based fluorometric biosensor for label free and homogenous detection of protein acetylation related enzymes activities. Biosensors and Bioelectron 91: 400-407.

96. Wang Z, Yan Z, Wang F, Cai J, Guo L, et al. (2017) Highly sensitive photoelectrochemical biosensor for kinase activity detection and inhibition based on the surface defect recognition and multiple signal amplification of metal-organic frameworks. Biosens Bioelectron 97: 107-114.

97. Kilic T, Soler M, Fahimi KN, Altug H, Carrara S (2018) Mining the potential of label-free biosensors for in vitro antipsychotic drug screening. Biosensors 8(1): E6.

98. Bengtson HN, Homolka S, Niemann S, Reis AJ, da Silva PE, et al. (2017) Multiplex detection of extensively drug resistant tuberculosis using binary deoxy ribozyme sensors. Biosens. Bioelectron 94: 176-183.

99. Ensafi AA, Nasr Esfahani P, Rezaei B (2017) Quenching recovery fluorescent biosensor for DNA detection based on mercaptopropionic acid-capped cadmium telluride quantum dots aggregation. Sensors and Actuators B Chemical 249: 149-155.

100. Savalia R, Chatterjee S (2017) Sensitive detection of brucine an antimetastatic drug for hepatocellular carcinoma at carbon nanotubesnation composite based biosensor. Biosens Bioelectron 98: 371-377.

101. Cui HF, Wu WW, Li MM, SongX, Lv Y, et al. (2018) A highly stable acetylcholinesterase biosensor based on chitosan-TiO2-graphene nanocomposites for detection of organophosphate pesticides. Biosens Bioelectron 99: 223-229.

102. Vaghela C, Kulkarni M, Haram S, Aiyer R, Karve, M (2018) A novel inhibition-based biosensor using urease nanoconjugate entrapped biocomposite membrane for potentiometric glyphosate detection. Int ] Biol Macromol 108: 32-40.

103. Zhou L, Zhang X, Ma L, Gao J, Jiang Y (2017) Acetylcholinesterase/ chitosan-transition metal carbides nanocomposites-based biosensor for the organophosphate pesticides detection. Biochem Eng J 128: 243-249.

104. Mishra A, Kumar J, Melo JS (2017) An optical microplate biosensor for the detection of methyl parathion pesticide using a biohybrid of Sphingomonas sp cells-silica nanoparticles. Biosens Bioelectron 87 332-338.

105. Nguyen VT, Kwon YS, Gu MB (2017) Aptamer-based environmental biosensors for small molecule contaminants. Current Opinion in Biotechnol 45: 15-23.

106. Lu X, Tao L, Song D, Li Y, Gao F (2018) Bimetallic Aunanorods based ultrasensitive acetylcholinesterase biosensor for determination of organophosphate pesticides. Sens Actuators B Chem 255: 2575-2581.

107. Bala R, Dhingra S, Kumar M, Bansal K, Mittal S, et al. (2017) Detection of organophosphorus pesticide-Malathion in environmental samples using peptide and aptamer based nanoprobes. Chem Eng J 311: 111116.

108. Zheng Q, Chen Y, Fan K, Wu J, Ying Y (2017) Exploring pralidoxime chloride as a universal electrochemical probe for organophosphorus pesticides detection. Analytica Chimica Acta 982: 78-83.

109. Cinti S, Minotti C, Moscone D, Palleschi G, Arduini F (2017) Fully integrated ready-to-use paper-based electrochemical biosensor to detect nerve agents. Biosens Bioelectron 93: 46-51.

110. He L, Cui B, Liu J, Song Y, Wang M, et al. (2018) Novel electrochemical biosensor based on core-shell nanostructured composite of hollow carbon spheres and polyaniline for sensitively detecting malathion. Sens Actuators B Chem 258: 813-821.

111. Song D, Li Y, Lu X, Sun M, Liu H, et al. (2017) Palladium-copper nanowires-based biosensor for the ultrasensitive detection of organophosphate pesticides. Anal Chim Acta 982: 168-175

112. Sarkar T, Narayanan N, Solanki PR (2017) Polymer-clay nanocompositebased acetylcholine esterase biosensor for organophosphorous pesticide detection. Int J Environ Res 11(5-6): 591-601.

113. Hondred JA, Breger JC, Alves NJ, Trammell SA, Walper SA, et al (2018) Printed graphene electrochemical biosensors fabricated by inkjet maskless lithography for rapid and sensitive detection of organophosphates. ACS Appl Mater Interfaces 10(13): 11125-11134.

114. Rajangam B, Daniel DK, Krastanov AI (2018) Progress in enzyme inhibition based detection of pesticides. Eng Life Sci 18(1): 4-19.

115. Bagheri H, Afkhami A, Khoshsafar H, Hajian A, Shahriyari A (2017) Protein capped $\mathrm{Cu}$ nanoclusters-SWCNT nanocomposite as a novel candidate of high performance platform for organophosphates enzyme less biosensor. Biosens Bioelectron 89: 829-836.

116. Fang Y, Tian W, Pei F, Li P, Shao X, et al. (2017) Simultaneous determination of pesticide residues and antioxidants in blended oil using a liquid-liquid extraction combined with dispersive solid phase extraction method. Food Chem 229: 347-353.

117. Nielsen GD, Larsen ST, Wolkoff P (2017) This review discusses the past and recent advancements of biosensors focusing on detection of Organophosphorus Pesticides (OPs) due to their exceptional use during the last decades. Apart from agricultural benefits, OPs also impose adverse toxicological effects on animal and human population. Conventional approaches such as chromatographic techniques used for pesticide detection are associated with... Arch Toxicol 91: 109-130.

118. Nasir MZM, Mayorga-Martinez CC, Sofer Z, Pumera M (2017) Twodimensional 1T-phase transition metal dichalcogenides as nanocarriers to enhance and stabilize enzyme activity for electrochemical pesticide detection. ACS Nano 11(6): 5774-5784.

119. Wang B, Zhong X, Chai Y, Yuan R (2017) Ultrasensitive electrochemiluminescence biosensor for organophosphate pesticides detection based on carboxylated graphitic carbon nitride-poly (ethylenimine) and acetylcholinesterase. Electrochimica Acta 224: 194-200.

120. Majeed A, Najar RA, Choudhary S, Rehman WU, Singh A, et al. (2017) Practical and plausible implications of chitin- and chitosan-based nanocomposites in agriculture. In Chitosan (Wiley-Blackwell), pp. 409-430.

121. Thangavelu D, Annamalai P, Govindan G, Ramadoss M, Sivakumar PK, et al. (2018) Recent advances in polymer supporting layered double hydroxides nanocomposite for electrochemical biosensors. Materials Research Express 5(1).

122. Naseri M, Fotouhi L, Ehsani A (2018) Recent progress in the development of conducting polymer-based nanocomposites for electrochemical biosensors applications: A mini-review Chem Rec 18(6): 599-618. 
123. Khan A, Abas Z, Kim HS, Kim J (2016) Recent progress on cellulosebased electro-active paper, its hybrid nanocomposites and applications. Sensors (Basel) 16(8): E1172.

124. Sisman A, Gur E, Ozturk S, Enez B, Okur B, et al. (2017) A low-cost biomarker-based SAW-biosensor design for early detection of prostate cancer. Procedia Technol. 27: 248-249.

125. Pan LH, Kuo SH, Lin TY, Lin CW, Fang PY et al. (2017) An electrochemical biosensor to simultaneously detect VEGF and PSA for early prostate cancer diagnosis based on graphene oxide/ssDNA/PLLA nanoparticles. Biosens Bioelectron 89(Pt 1): 598-605.

126. Ji S, Lee M, Kim D (2018) Detection of early stage prostate cancer by using a simple carbon nanotube@paper biosensor. Biosens Bioelectron 102: 345-350.

127. Azimzadeh M, Nasirizadeh N, Rahaie M, Naderi Manesh H (2017) Early detection of alzheimer's disease using a biosensor based on electrochemically-reduced graphene oxide and gold nanowires for the quantification of serum microRNA-137. RSC Advances 55709-55719.

128. Matsko A, Liu Z, Helton M, Hughes A, Reeves M (2017) Early detection of amylin aggregation with a miniature optical-fiber based sensor. Washington DC, USA

129. Fathi F, Rezabakhsh A, Rahbarghazi R, Rashidi MR (2017) Early-stage detection of VE-cadherin during endothelial differentiation of human mesenchymal stem cells using SPR biosensor. Biosens Bioelectron 96: 358-366.

130. Kaushik A, Tiwari S, Jayant RD, Vashist A, Nikkhah Moshaie R, et al. (2017) Electrochemical biosensors for early stage zika diagnostics. Trends Biotechnol 35(4): 308-317.

131. Afzal A, Mujahid A, Schirhagl R, Bajwa SZ, Latif U, et al. (2017) Gravimetric viral diagnostics: QCM based biosensors for early detection of viruses. Chemosensors 5(10): 7.

132. Ertürk G, Hedström M, Mattiasson B, Ruzgas T, Lood R (2018) Highly sensitive detection and quantification of the secreted bacterial benevolence factor Rox P using a capacitive biosensor: A possible early detection system for oxidative skin diseases. PloS One 13(3): e0193754.

133. Afsahi S, Lerner MB, Goldstein JM, Lee J, Tang X, et al. (2018) Nove graphene-based biosensor for early detection of zika virus infection. Biosens Bioelectron 100 85-88.

134. Pou SA, Osella AR, Eynard AR, Niclis C, Pilar Diaz M (2009) Colorectal cancer mortality trends in Córdoba, Argentina. Cancer Epidemiol 33(6): 406-412.

135. Van der Most RG, Robinson BWS, Lake RA (2005) Combining immunotherapy with chemotherapy to treat cancer. Discov. Med 5(27): 265-270.

136. Zhou Y, Li H, Yang YW (2015) Controlled drug delivery systems based on calixarenes. Chin Chem Lett 26(7): 825-828.

137. Schwingshackl L, Boeing H, Stelmach Mardas M, Gottschald M, Dietrich S, et al. (2017) Dietary supplements and risk of cause-specific death, cardiovascular disease, and cancer: a systematic review and metaanalysis of primary prevention trials. Syst Rev 26: 4-34.

138. Lüpertz R, Wätjen W, Kahl R, Chovolou Y (2010) Dose- and timedependent effects of doxorubicin on cytotoxicity, cell cycle and apoptotic cell death in human colon cancer cells. Toxicology 271(3): 115-121.

139. Reed JC (2006) Drug insight: cancer therapy strategies based on restoration of endogenous cell death mechanisms. Nat Clin Pract Oncol 3(7): 388-398

140. Wang H, Zhao Y, Wu Y, Hu Y, Nan K, et al. (2011) Enhanced anti-tumor efficacy by co-delivery of doxorubicin and paclitaxel with amphiphilic methoxy PEG-PLGA copolymer nanoparticles. Biomaterials 32(2): 8281-8290.

141. Igney FH, Krammer PH (2002) Immune escape of tumors: apoptosis resistance and tumor counterattack. J Leukoc Biol 71(6): 907-920.

142. Sadhukha T, Wiedmann TS, Panyam J (2013) Inhalable magnetic nanoparticles for targeted hyperthermia in lung cancer therapy. Biomaterials 34(21): 5163-5171.

143. Tong L, Ahn C, Symanski (2014) Temporal trends in the leading causes of death among a large national cohort of patients with colorectal cancer from 1975 to 2009 in the United States. Ann Epidemiol 24(6): 411-417.

144. Charles A Janeway J, Travers P, Walport M, Shlomchik MJ (2001) Using the immune response to attack tumors, New York, USA.

145. Ferenhof HA, Fernandes RF (2016) Demystifying the literature review as basis for scientific writing: SSF Method. Rev ACB 21: 550-563.

146. OECD (2014) OECD science technology and industry outlook 2014 OECD Publishing, France.

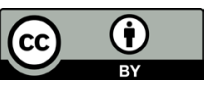

Creative Commons Attribution 4.0 International License

For possible submissions Click Here
Submit Article

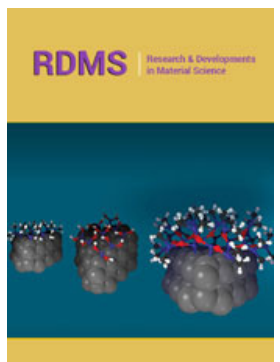

\section{Research \& Development in Material Science}

\section{Benefits of Publishing with us}

- High-level peer review and editorial services

- Freely accessible online immediately upon publication

- Authors retain the copyright to their work

- Licensing it under a Creative Commons license

- Visibility through different online platforms 